DE

M E D I C I N A

T R O P I C A L

$\mathrm{DE}$

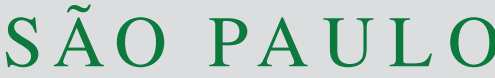

JOURNAL OF THE SÃO PAULO INSTITUTE OF TROPICAL MEDICINE

${ }^{1}$ Universidade de São Paulo, Faculdade de Medicina, Hospital das Clínicas, Unidade de Transplante de Medula Óssea, São Paulo, São Paulo, Brazil

2Universidade de São Paulo, Faculdade de Medicina, Hospital das Clínicas, Laboratório de Microbiologia, São Paulo, São Paulo,

Brazil

${ }^{3}$ Universidade de São Paulo, Instituto de Medicina Tropical de São Paulo, LIM-49, São Paulo, São Paulo, Brazil

${ }^{4}$ Universidade de São Paulo, Faculdade de Medicina, Departamento de Moléstias Infecciosas e Parasitárias, São Paulo, São Paulo, Brazil

Correspondence to: Silvia Figueiredo Costa

Universidade de São Paulo, Faculdade de Medicina, Departamento de Moléstias Infecciosas e Parasitárias, Av. Eneias Carvalho de Aguiar, 255, CEP 05403-000, São Paulo, SP, Brazil

Tel: +55 11996422865

E-mail: silviacosta@usp.br

Received: 11 January 2020

Accepted: 24 June 2020

\section{Capnocytophaga sputigena bloodstream infection in hematopoietic stem cell transplantations: two cases report and review of the literature}

Fernanda Rodrigues Mendes ${ }^{1}$, Felipe Ribeiro Bruniera ${ }^{1}$, Jayir Schmidt ${ }^{1}$, Ana Paula Cury², Camila Rizeck³ ${ }^{3}$ Hermes Higashino ${ }^{4}$, Fernando Nivaldo Oliveira ${ }^{4}$, Flavia Rossi ${ }^{2}$, Vanderson Rocha ${ }^{1}$, Silvia Figueiredo Costa ${ }^{(-3,4}$

\section{ABSTRACT}

Capnocytophaga is a group of facultative anaerobic gram-negative bacteria present in the oral cavity of humans, dogs and cats, as part of their normal oral flora. Here, we described two cases of bloodstream infections (BSI) caused by Capnocytophaga in neutropenic autologous hematopoietic stem cell transplantation (auto-HSCT) patients with mucositis (Grade I and Grade III) identified by Maldi-Tof. They were successfully treated with $\beta$-lactam (meropenem and piperacillin-tazobactam). The species $C$. sputigena was confirmed by $16 \mathrm{~S}$ rRNA gene sequencing in one patient. The review of literature showed that $C$. ochraceae was the most frequent species causing BSI in auto-HSCT patients and that the patients usually presented mucositis and were neutropenic at the onset of the infection.

KEYWORDS: Capnocytophaga. Bloodstream infection. Hematopoietic stem cell transplantation.

\section{INTRODUCTION}

Capnocytophaga is a group of facultative anaerobic gram-negative bacteria, belonging to the Flavobacteriaceae family. These organisms are present in the oral cavity of humans, dogs and cats, as part of their normal oral flora ${ }^{1,2}$. Up to now, there are nine Capnocytophaga species reported in human oral microbiota: C. gingivalis, C. granulosa, C. haemolytica, C. leadbetteri, C. ochracea, C. sputigena, C. genospecies AHN8471; while C. canimorsusand C. cynodegmi are described in the oral microbiota of dogs and cats ${ }^{3}$. All the species have been reported as pathogens in humans.

Capnocytophaga spp. has been described as cause of bloodstream infections (BSI), both in immunocompetent and immunocompromised hosts. Although mucositis is very frequent during chemotherapy, up to now, few cases of BSI caused by Capnocytophaga have been reported in hematopoietic stem cell transplantation (HSCT) patients ${ }^{4-9}$.

We described here two cases of Capnocytophaga BSI in autologous HSCT (auto-HSCT) patients at the Bone Marrow Transplantation Unit of Hospital das Clinicas of University of Sao Paulo observed in 2018, and we also reviewed the main aspects concerning this infection in the literature. 


\section{CASE REPORT}

\section{Case 1}

A 23-year-old man who had been diagnosed with Hodgkin's Lymphoma in 2015 with an IIA initial stage and refractoriness to multiple chemotherapy regimens was admitted to the bone marrow transplantation ward. The patient was submitted to an autologous stem cell transplantation (auto-HSCT) after a conditioning with CBV (cyclophosphamide-carmustine-etoposide).

The patient had a history of obesity grade III, with a body mass index (the weight in kilograms divided by the square of the height in meters) of 53.76 on the admission's day, systemic arterial hypertension and onychomycosis in both feet. He lived with his parents and two younger brothers and had two dogs that were kept outdoors.

The patient was colonized by K. pneumonia carbapenemresistant and VRE, he had mobilized peripheral blood progenitor cells (PBPCs) during the chemotherapy with gemcitabine plus vinorelbine in March 2018 with $1,800 \mathrm{mcg}$ of GCSF and collected $5.8 \times 10^{6} \mathrm{CD} 34+$ cell per kg/body weight by a long-term hemodialysis catheter (permcath) that was preserved for the PBPCs infusion. During this hospitalization, he used prophylaxis against infections with a single dose of ivermectin, cotrimoxazole until D-1, fluconazole in the neutropenic period and acyclovir. On day +1 the patient complained of mouth pain due to grade I oral mucositis, even if he had been on laser prophylaxis daily. On day +2 he presented with low-grade axillar fever $\left(37.8^{\circ} \mathrm{C}\right)$ and chills, so that blood and urine cultures were taken and he was started on meropenem ( $2 \mathrm{~g}$ de $8 / 8 \mathrm{~h})$. As the patient continued to present with daily fever and the C-reactive protein increased to $173 \mathrm{mg} / \mathrm{L}$ on day +4 , blood culture taken through a peripheral vein yielded a gram-negative rod on D+5 and the medical team decided to introduce amikacin and vancomycin,

On day +7 , the laboratory identified Capnocytophaga spp. in blood cultures from the peripheral vein using MaldiTof (BioMérieux, France, Crapone, France) and the catheter was removed on the same day. As the neutrophils grafting happened on day +9 and the skin infection got better, grampositive coverage was discontinued and the patient finished a 10 day-treatment with meropenem.

The 16S rRNA gene sequencing was performed through the MicroSeq 500 system (AppliedBiosystems, Foster City, CA, USA) with PCR and sequencing kits designed with universal primers to cover all the bacteria, as the biochemical methods did not identify the Capnocytophaga species. Sequences were analyzed by using an ABI PRISM 3730 Series DNA Analyzer (Applied Biosystems, Foster city, CA, USA) and showed $100 \%$ identity with the GenBank sequence MH078434.1 (C. sputigena).

\section{Case 2}

A 50-year-old male who had been diagnosed with Peripheral T-cells NOS Lymphoma in 2017 was admitted to the bone marrow transplantation ward to receive an auto-HSCT.

He lived with his family and had a dog that lived in the same house. He was colonized with VRE five months prior to this ward admission. During this hospitalization, he was submitted to CBV (cyclophosphamide-carmustineetoposide) conditioning, used prophylaxis against infections with a single dose of ivermectin, cotrimoxazole until D-1, fluconazole in the neutropenic period and acyclovir.

On day $\mathrm{D}+2$ his leukocyte count came down to less than 500. On day D+4 he experienced grade III mucositis, even receiving laser prophylaxis daily. The $\mathrm{C}$-reactive protein increased to $321 \mathrm{mg} / \mathrm{L}$ on day +7 and he presented with fever $\left(38.1{ }^{\circ} \mathrm{C}\right)$ without chills. He was started on linezolid and piperacillin tazobactam, as he was diagnosed with severe mucositis and febrile neutropenia.

As the patient's condition improved, he remained for 48 hours without fever and the neutrophils grafting happened on day +11 , so that the medical team decided to discontinue the antibiotic. On day +10 the blood culture from the catheter yielded a gram-negative rod and on D+14 the laboratory identified Capnocytophaga spp. using Maldi Tof (BioMérieux, France, Crapone, France). The blood cultures from the peripheral veins resulted negative and the catheter was removed.

The most important clinical and microbiological characteristics of our case report and the review of cases of Capnocytophaga spp. BSI in HSCT patients described in the literature are shown in Table 1.

\section{DISCUSSION}

We described two cases of BSI caused by Capnocytophaga in neutropenic auto-HSCT patients with mucositis, that were successfully treated with $\beta$-lactam (meropenem and piperacillin-tazobactam). The CVC was removed in both patients and the species $C$. sputigena was confirmed by sequencing in one patient.

Although C. sputigena is part of the human oropharyngeal microbiota, it has been reporting causing infections in neutropenic patients with mucositis ${ }^{10-11}$. Capnocytophaga sputigena BSI has been described as well in non-neutropenic patients ${ }^{12}$. A recent report described a patient with diabetes mellitus and gastric cancer that 
Table 1 - Clinical and microbiological characteristics of BSI by Capnocytophaga spp in HSCT patients described in the literature and in these two cases report.

\begin{tabular}{|c|c|c|c|c|c|c|c|c|c|c|}
\hline Articles & Isolated species & $\begin{array}{c}\text { Site of } \\
\text { infection }\end{array}$ & $\begin{array}{l}\text { Underlying } \\
\text { disease }\end{array}$ & $\begin{array}{l}\text { Type of } \\
\text { HSCT }\end{array}$ & Mucositis & $\begin{array}{l}\text { Day of sepsis } \\
\text { onset after } \\
\text { HSCT }\end{array}$ & $\begin{array}{c}\text { Risk fator for } \\
\text { BSI }\end{array}$ & Treatment & $\begin{array}{l}\text { Identification of } \\
\text { bacteria }\end{array}$ & Outcome \\
\hline Ugai et al. ${ }^{4}$ & C. canimorsus & $\begin{array}{l}\text { Blood } \\
\text { stream } \\
\text { infection }\end{array}$ & $\begin{array}{l}\text { acute } \\
\text { myeloid } \\
\text { leukemia }\end{array}$ & $\begin{array}{l}\text { mismatched } \\
\text { unrelated donor }\end{array}$ & No & $\begin{array}{c}7 \text { years } \\
\text { earlier HSCT }\end{array}$ & $\begin{array}{l}\text { Chronic GVHD, } \\
\text { but no IST; } \\
\text { marked splenic } \\
\text { atrophy on CT } \\
\text { history of licked } \\
\text { wound by a dog } \\
2 \text { days before } \\
\text { admission }\end{array}$ & $\begin{array}{l}\text { meropenem } \\
\text { and vancomycin } \\
\text { followed by } \\
\text { ceftriaxone }\end{array}$ & No data avaliable & Discharged \\
\hline $\begin{array}{l}\text { García-Cía } \\
\text { et al. }{ }^{5}\end{array}$ & $\begin{array}{l}\text { C. sputigena plus } \\
\text { Escherichia coli }\end{array}$ & $\begin{array}{l}\text { Blood } \\
\text { stream } \\
\text { infection }\end{array}$ & $\begin{array}{l}\text { Hodgkin's } \\
\text { lymphoma }\end{array}$ & $\begin{array}{l}\text { Autologous } \\
\text { HSCT }\end{array}$ & Yes & $D+2$ & Neutropenia & $\begin{array}{l}\text { amoxicillin/ } \\
\text { clavulanate } \\
\text { followed by } \\
\text { cefepime and } \\
\text { amikacin }\end{array}$ & No data avaliable & Discharged \\
\hline Bonatti et al. ${ }^{6}$ & C. ochraceae & $\begin{array}{l}\text { Blood } \\
\text { stream } \\
\text { infection }\end{array}$ & $\begin{array}{l}\text { chronic } \\
\text { myelogenous } \\
\text { leukemia }\end{array}$ & $\begin{array}{l}\text { No data } \\
\text { available }\end{array}$ & Yes & $\mathrm{D}+9$ & Neutropenia & $\begin{array}{l}\text { Cefandamole, } \\
\text { amikazin } \\
\text { vancomycin } \\
\text { followed by } \\
\text { Imipenem- } \\
\text { cilastatin, PenG }\end{array}$ & $\begin{array}{c}\text { RAPID-ANA II System } \\
\text { (Innovative Diagnostic } \\
\text { Systems, Inc., } \\
\text { Norcross, GA, USA); } \\
\text { Restriction fragment } \\
\text { length polymorphism } \\
\text { (RFLP) }\end{array}$ & Discharged \\
\hline Bonatti et al. ${ }^{6}$ & C. ochraceae & $\begin{array}{l}\text { Blood } \\
\text { stream } \\
\text { infection }\end{array}$ & $\begin{array}{l}\text { chronic } \\
\text { myelogenous } \\
\text { leukemia }\end{array}$ & $\begin{array}{l}\text { No data } \\
\text { available }\end{array}$ & Yes & $D+9$ & Neutropenia & $\begin{array}{l}\text { Cefamandole, } \\
\text { tobramycin, } \\
\text { vancomycin } \\
\text { followed by } \\
\text { Piperacillin- } \\
\text { tazobactam }\end{array}$ & $\begin{array}{c}\text { RAPID-ANA II System } \\
\text { (Innovative Diagnostic } \\
\text { Systems, Inc., } \\
\text { Norcross, GA, USA); } \\
\text { Restriction fragment } \\
\text { length polymorphism } \\
\text { (RFLP) } \\
\end{array}$ & Discharged \\
\hline Bonatti et al. ${ }^{6}$ & C. ochraceae & $\begin{array}{l}\text { Blood } \\
\text { stream } \\
\text { infection }\end{array}$ & $\begin{array}{l}\text { acute myeloid } \\
\text { leukemia }\end{array}$ & $\begin{array}{l}\text { No data } \\
\text { available }\end{array}$ & Yes & $D+6$ & Neutropenia & $\begin{array}{l}\text { Cefamandole, } \\
\text { amikacin } \\
\text { vancomycin } \\
\text { followed by } \\
\text { Imipenem- } \\
\text { cilastatin }\end{array}$ & $\begin{array}{l}\text { RAPID-ANA II System } \\
\text { (Innovative Diagnostic } \\
\text { Systems, Inc., } \\
\text { Norcross, GA, USA); } \\
\text { Restriction fragment } \\
\text { length polymorphism } \\
\text { (RFLP) }\end{array}$ & Discharged \\
\hline Bonatti et al. ${ }^{6}$ & $\begin{array}{c}\text { Capnocytophaga } \\
\text { sp }\end{array}$ & $\begin{array}{l}\text { Blood } \\
\text { stream } \\
\text { infection }\end{array}$ & $\begin{array}{l}\text { chronic } \\
\text { myelogenous } \\
\text { leukemia }\end{array}$ & $\begin{array}{l}\text { No data } \\
\text { available }\end{array}$ & Yes & $D+8$ & Neutropenia & $\begin{array}{l}\text { Cefamandole } \\
\text { followed by } \\
\text { Imipenem- } \\
\text { cilastatin }\end{array}$ & $\begin{array}{l}\text { RAPID-ANA II System } \\
\text { (Innovative Diagnostic } \\
\text { Systems, Inc., } \\
\text { Norcross, GA, USA) }\end{array}$ & Discharged \\
\hline Geisler et al. ${ }^{7}$ & C. gingivalis & Pneumonia & $\begin{array}{l}\text { Acute } \\
\text { myelogenous } \\
\text { leukemia }\end{array}$ & $\begin{array}{c}\text { Autologous } \\
\text { HSCT }\end{array}$ & Yes & $\begin{array}{l}\text { No data } \\
\text { avaliable }\end{array}$ & Neutropenia & $\begin{array}{l}\text { Gentamicin and } \\
\text { levofloxacin } \\
\text { followed by } \\
\text { linezolid and } \\
\text { metronidazole }\end{array}$ & $\begin{array}{l}\text { Morphology and the } \\
\text { following biochemical } \\
\text { reactions }\end{array}$ & Discharged \\
\hline Bilgrami et al. ${ }^{8}$ & $\begin{array}{c}\text { Capnocytophaga } \\
\text { sp }\end{array}$ & $\begin{array}{l}\text { Blood } \\
\text { stream } \\
\text { infection }\end{array}$ & $\begin{array}{l}\text { Hodgkin's } \\
\text { disease }\end{array}$ & $\begin{array}{c}\text { Autologous } \\
\text { HSCT }\end{array}$ & Yes & $D+3$ & Neutropenia & $\begin{array}{l}\text { Ceftazidime } \\
\text { and clindamycin } \\
\text { followed by } \\
\text { ampicillin }\end{array}$ & $\begin{array}{l}\text { API AN-Ident System } \\
\text { (Analytic Products, } \\
\text { Plainview, NY) }\end{array}$ & Discharged \\
\hline Baquero et al. ${ }^{9}$ & C. ochraceae & $\begin{array}{l}\text { Blood } \\
\text { stream } \\
\text { infection }\end{array}$ & $\begin{array}{l}\text { acute myeloid } \\
\text { leukemia }\end{array}$ & $\begin{array}{c}\text { Autologous } \\
\text { HSCT }\end{array}$ & Yes & $\mathrm{D}+2$ & Neutropenia & $\begin{array}{l}\text { Ceftazidime } \\
\text { amikacin } \\
\text { followed by } \\
\text { piperacillin and } \\
\text { subsequently } \\
\text { clindamycin }\end{array}$ & $\begin{array}{l}\text { Morphology and the } \\
\text { following biochemical } \\
\text { reactions }\end{array}$ & Discharged \\
\hline This report & $\begin{array}{c}\text { Capnocytophaga } \\
\mathrm{sp}\end{array}$ & $\begin{array}{l}\text { Blood } \\
\text { stream } \\
\text { infection }\end{array}$ & $\begin{array}{l}\text { Hodgkin's } \\
\text { lymphoma }\end{array}$ & $\begin{array}{l}\text { Autologous } \\
\text { HSCT }\end{array}$ & Yes & $D+5$ & Neutropenia & Meropenem & MALDI-TOF & Discharged \\
\hline This report & $\begin{array}{l}\text { Capnocytophaga } \\
\mathrm{sp}\end{array}$ & $\begin{array}{l}\text { Blood } \\
\text { stream } \\
\text { infection }\end{array}$ & $\begin{array}{l}\text { Peripheral } \\
\text { T-cells NOS } \\
\text { Lymphoma }\end{array}$ & $\begin{array}{l}\text { Autologous } \\
\text { HSCT }\end{array}$ & Yes & $D+10$ & Neutropenia & $\begin{array}{l}\text { Piperacillin } \\
\text { tazobactam }\end{array}$ & $\begin{array}{c}\text { MALDI-TOF } \\
\text { 16sRNA sequencing }\end{array}$ & Discharged \\
\hline
\end{tabular}

developed an infection by $C$. sputigena ${ }^{12}$. It is a rare opportunistic pathogen that causes infection in HSCT patients. Here we described the first case of BSI caused by C. sputigena in an auto-HSCT patient. So far, C. ochraceae has been reported as the most frequent species causing BSI in this population of patients, mainly during neutropenia and in patients with mucosistis ${ }^{9}$.

The two Capnocytophaga's infections reported in this article illustrated the hazardous potential of this bacteria to cause BSI coinciding with the onset of mucositis, which represents the main portal of entry for this organism, particularly the $C$. sputigena, during the conditioning regimen for auto-HSCT. Moreover, our report highlights the importance of a good oral hygiene and the multidisciplinary team care procedures such as the laser prophylaxis in the peri-transplantation period. Interestingly, both patients had previous contact with dogs and presented mucositis as well. Thus, the species identification is essential to establish that the source of infection and in our patients it was probably the mucositis. Regrettably, we could identify the species by 
16SRNA sequencing as $C$. sputigena in only one patient. This is a limitation of our report as the species identification is key to implementinfection control measures and patients care as the species can hypothesize the source of infection such as the animal contact ${ }^{10}$.

Since there is no Clinical \& Laboratory Standards Institute (CLSI) nor European Committee on Antimicrobial Susceptibility Testing (EUCAST) recommendation for susceptibility break points for this genus; the spectrum of antibiotics and the duration of treatment is based on clinical reports ${ }^{13}$. Antimicrobial susceptibility of Capnocytophaga spp. using different methods have shown that clindamycin, linezolid, tetracycline, chloramphenicol, imipenem and $\beta$-lactamase inhibitor combinations displayed in vitro activities against this bacterium. In contrast, most strains are reported as resistant to polymyxin, fusidic acid, fosfomycin and trimethoprim ${ }^{13}$. A recent study, however, demonstrated that a high proportion of Capnocytophaga sputigena isolates were $\beta$-lactamase-positive and that $\beta$-lactamresistant isolates, resistant to amoxacillin, amoxacillin plus clavulanic acid and third generation cephalosporins, harboured the $\beta$-lactamase genes bla $\mathrm{CfxA}_{\mathrm{A}}$ or bla ${ }_{\mathrm{CSP}-1}{ }^{14}$. CSP-1 is a novel extended-spectrum $\beta$-lactamase produced by a clinical isolate of $C$. sputigena ${ }^{15}$. Thus, it is important to highlight that $C$. sputigena carrying $\beta$-lactamase genes can be resistant to amoxacillin, amoxacillin plus clavulanic acid and third generation cephalosporins.

\section{CONCLUSION}

Capnocytophaga sputigena BSI can occur in autoHSCT neutropenic patients with mucositis mainly during neutropenia and can be successfully treated with meropenem or piperacillin tazobactam. This report highlights the importance of Capnocytophaga species identification to guide the HSCT patients' care as well as preventive measures during the peri-transplantation period.

\section{CONFLICT OF INTERESTS}

On behalf of all authors, the corresponding author states that there is no conflict of interest.

\section{REFERENCES}

1. Pokroy-Shapira E, Shiber S, Molad Y. Capnocytophaga bacteraemia following Rituximab treatment. BMJ Case Rep. 2012;2012:bcr2012006224.

2. Piau C, Arvieux C, Bonnaure-Mallet M, Jolivet-Gougeon A. Capnocytophaga spp. involvement in bone infections: a review. Int J Antimicrob Agents. 2013;41:509-15.
3. Popiel KY, Vinh DC. 'Bobo-Newton syndrome': an unwanted gift from man's best friend. Can J Infect Dis Med Microbiol. 2013;24:209-14.

4. Ugai T, Sugihara H, Nishida Y, Yamakura M, Takeuchi M, Matsue K. Capnocytophaga canimorsus sepsis following BMT in a patient with AML: possible association with functional asplenia. Bone Marrow Transplant. 2014;49:153-4.

5. García-Cía JI, Esteban J, Santos-O’Connor F, Román A, Soriano F. Mixed bacteremia with Capnocytophaga sputigena and Escherichia coli following bone marrow transplantation: case report and review. Eur J Clin Microbiol Infect. Dis. 2004;23:139-41.

6. Bonatti H, Rossboth DW, Nachbaur D, Fille M, Aspöck C, Hend I, et al. A series of infections due to Capnocytophaga spp in immunosuppressed and immunocompetent patients. Clin Microbiol Infect. 2003;9:380-7.

7. Geisler WM, Malhotra U, Stamm WE. Pneumonia and sepsis due to fluoroquinolone-resistant Capnocytophaga gingivalis after autologous stem cell transplantation. Bone Marrow Transplant. 2001;28:1171-3.

8. Bilgrami S, Bergstrom SK, Peterson DE, Hill DR, Dainiak N, Quinn JJ, et al. Capnocytophaga bacteremia in a patient with Hodgkin's disease following bone marrow transplantation: case report and review. Clin Infect Dis. 1992;14:1045-9.

9. Baquero F, Fernández J, Dronda F, Erice A, Pérez de Oteiza J, Reguera JA, et al. Capnophilic and anaerobic bacteremia in neutropenic patients: an oral source. Rev Infect Dis. 1990;12 Suppl 2:S157-60

10. García Lozano T, Lorente Alegre P, Linares Latorre MD, Aznar Oroval E. Bacteriemia fulminante asociada a Capnocytophaga sputigena en un paciente con linfoma no Hodgkin tipo T: diagnóstico por secuenciación genética del ARNr 16S. Rev Argent Microbiol. 2012;44:170-2.

11. Martino R, Ramila E, Capdevila J, Planes A, Rovira M, Ortega $\mathrm{M}$, et al. Bacteremia caused by Capnocytophaga species in patients with neutropenia and cancer: results of a multicenter study. Clin Infect Dis. 2001;33:E20-2.

12. Ramirez I. Capnocytophaga sputigena bacteremia in a neutropenic host. IDCases. 2019;17:e0536.

13. Lo SH, Chang YY, Jao YT, Wang WH, Lu PL, Chen YH. Capnocytophaga sputigena pneumonia and bacteremia in a patient with diabetes and gastric cancer. J Microbiol Immunol Infect. 2018;51:578-9.

14. Ehrmann E, Handal T, Tamanai-Shacoori Z, Bonnaure-Mallet M, Fosse T. High prevalence of $\beta$-lactam and macrolide resistance genes in human oral Capnocytophaga species. J Antimicrob Chemother. 2014;69:381-4.

15. Guillon H, Eb F, Mammeri H. Characterization of CSP-1, a novel extended-spectrum $\beta$-Lactamase produced by a clinical isolate of Capnocytophaga sputigena. Antimicrob Agents Chemother. 2010;54:2231-4. 